\title{
Penerapan Metode Praktikum untuk Meningkatkan Keterampilan Proses Sains Dan Hasil Belajar IPA Fisika Peserta Didik Pada Materi Pokok Getaran dan Gelombang Kelas VIII SMP Negeri 2 Bungku Selatan
}

\author{
Hadija $^{1)}$, Muhammad Anas ${ }^{2)}$, La Tahang ${ }^{2)}$ \\ ${ }^{1}$ Alumni Jurusan Pendidikan Fisika, FKIP Universitas Halu Oleo, Jl. H.E.A Mokodompit, Kendari 93232 \\ ${ }^{2}$ Dosen Jurusan Pendidikan Fisika, FKIP Universitas Halu Oleo, Jl. H.E.A Mokodompit, Kendari 93232 \\ Email: dija.hadija97@gmail.com
}

\begin{abstract}
This study aims to find out 1) The description of pros science skills and learning outcomes of experimental class students and control class students before and after research on the subject matter of vibration and waves. 2) The difference between the average value of the pre-test results of the students of the experimental class and the average value of the pre-test results of the control class students on the subject matter of vibration and waves. 3) The average value of the post-test results of the experimental class students is significantly better than the average value of the post-test results of the control class students on the subject matter of vibration and wave. 4) Difference between experimental class learning outcomes and control class science process skills. 5) Difference between control class learning outcomes and experimental class science process skills. The population of this research is all eighth grade students of SMPN 2 Bungku Selatan in the even semester of the 2018/2019 academic year, totaling 54 homogeneous students. The description of the pretest and post-test results of experimental class students on the subject matter of vibration and waves is the average value of the pre-test of 36.195 and a standard deviation of 9.55, for the post-test an average value of 77.609, and a standard deviation of 10.985 , while in the control class the average value of the pre-test was 37.542 and the standard deviation was 10.592, for the post-test the average value was 71.044 and the standard deviation was 9.773. The results of the science process skills of the experimental class students are the average score of LKPD 01 2.6, LKPD 02 2.7, and LKPD 03 2.9, while for the science process skills of the control class students are the average scores of LKPD 01 scores 2,5, LKPD 02 2.7, and LKPD 03 2.8, with the same category that is enough categories. There is no difference between the average value of pre-test learning outcomes of experimental class students with the control group's average pre-test scores. The mean post-test scores of the experimental class students were significantly better than the control group's average post-test scores.
\end{abstract}

Keywords: Practicum method; Learning outcomes; Science process skills

\begin{abstract}
Abstrak: Penelitian ini bertujuan untuk mengetahui 1) Gambaran keterampilan pros sains dan hasil belajar peserta didik kelas eksperimen dan peserta didik kelas kontrol sebelum dan sesudah penelitian pada materi pokok getran dan gelombang. 2) Perbedaan antara nilai rata-rata hasil pre-test pesserta didik kelas eksperimen dengan nilai rata-rata hasil pre-test peserta didik kelas kontrol pada materi pokok getaran dan gelombang. 3) Nilai rata-rata hasil post-test peserta didik kelas eksperimen lebih baik secara signifikan dari pada nilai ratarata hasil post-test peserta didik kelas kontrol pada materi pokok getaran dan glombang. 4) Perbedaan hasil belajar kelas eksperimen dengan keterampilan proses sains kelas kontrol. 5) Perbedaan hasil belajar kelas kontrol dengan keterampilan proses sains kelas eksperimen. Populasi penelitian ini adalah seluruh siswa kelas VIII SMPN 2 Bungku Selatan pada semester genap tahun pelajaran 2018/2019 yang berjumlah 54 peserta didik yang bersifat homogen. Gambaran hasil pre-test dan post-test peserta didik kelas eksperimen pada materi pokok getaran dan gelombang yaitu nilai rata-rata pre-test sebesar 36,195 dan standar deviasi 9,55, untuk posttest nilai rata-rata 77,609, dan standar deviasi 10,985, sedangkan pada kelas kontrol yaitu nilai rata-ratapre-test sebesar 37,542 dan standar deviasi 10,592, untuk post-test nilai rata-rata 71,044 dan standar deviasi 9,773. Hasil keterampilan proses sains peserta didik kelas eksperimen yaitu nilai rata-rata skor LKPD 01 2,6, LKPD 02 2,7, dan LKPD 03 2,9, sedangkan untuk keterampilan proses sains peserta didik kelas kontrol yaitu nilai rata-rata skor LKPD 01 2,5, LKPD 02 2,7, dan LKPD 03 2,8, dengan kategori yang sama yaitu kategori cukup. Tidak ada perbedaan antara nilai rata-rata hasil belajar pre-test peserta didik kelas eksperimen dengan nilai rata-rata pre-test peserta didik kelas kontrol. Nilai rata-rata post-test peserta didik kelas eksperimen lebih baik secara signifikan daripada nilai rata-rata post-test peserta didik kelas kontrol.
\end{abstract}

Kata Kunci: Metode praktikum; Hasil belajar; Keterampilan proses sains 


\section{PENDAHULUAN}

Pendidikan merupakan faktor yang sangat penting dalam kehidupan manusia, karena dengan pendidikan diharapkan manusia dapat mengembangkan pengetahuan, keterampiilan dan kreatiivitas. Sesuai dengan Undang-Undang Republik Indonesia Nomor 20 tahun 2003 tentang sistem Pendidikan Nasional Bab 1 Pasal 1 yang berbunyi pendidikan adalah usaha sadar dan terencana untuk mewujudkan suasana belajar dan proses pembelajaran agar pesertaa scara akttif mengembangkan potensi dirinya untuk memiliki kekuatan spiritual keagamaan, pengendalian diri, kepribadian, kecrdasan akhlak mulia, serta keterampilan yang diperlukan dirinya, masyarakat, bangsa dan Negara. Tujuan pendidikan yang telah ditetapkan harus dicapai dengan optimal oleh lembaga pendidikan, akan tetapi hal ini tidak mudah karena banyak sekali masalah yang ditemui dalam pelaksanaannya. Lembaga pendidikan jalur sekolah yang menyelenggarakan kegiatan pendidikan, seringkali dihadapkan dengan berbagai permasalahan, diantaranya adalah pembelajaran.

Pembelajaran fisika dilakukan dengan memberikan metode pembelajaran yang tepat untuk tiap-.tiap materi. Hal ini dikarenakan pada tiap-tiap materi dalam fisika memiliki karakteristik tersendiri. Beberapa teknik yang dapat diterapkan dalam mempelajari fisika disesuaikan dengan sifat-sifat khas dari ilmu fisika, seperti mengaitkan dengan kehidupan sehari-hari, mempelajari fisika dengan pemahaman konsep, menggunakan berbagai teknik menghafal dan penyelesaian masalah di laboratorium. Kegiatan di laboratorium merupakan suatu proses penemuan yaitu melakukan kegiatan ilmiah dari teori yang telah dipelajari, permasalahan yang terjadi pada sekolah SMPN 2 Bungku Selatan peserta didik belum melakukan kegiatan tersebut salah satunya pada materi getaran dan gelombang, di sekolah tersebut memiliki laboratorium fisika dan alat yang cukup memadai namun untuk melakukan praktkum dan cara penggunaan alatalatnya peserta didik belum diajarkan.

Pendekatan keterampilan proses sains (KPS) merupakan pendekatan pembelajaran yang berorientasi pada proses IPA. Menurut Trianto (2013: 144), ketrampilan proses sains merupakan keseluruhan ketrampilan ilmiah yang terarah yang dapat digunakan untuk menemukan suatu prinsip atau teori, untuk mengembangkan teori yang sudah ada sebelumnya ataupun untuk melakukan penyangkalan terhadap suatu penemuan/flasisikasi.

Berdasarkan hasil TIMMS (Trand in Mathematics and Science Study) tahun 2011, penilaian yang dilakukan International of Education Achievement Study Center BostosCollage tersebut, kemendikbut (2012:37) menunjukkan bahwa Indonesia berada diurutan ke-40 dengan skor 400 dari 42 negara di bidang sains. Skor tes sains siswa di Indonesia ini turun 21 angka dibandiinngkan TIMMS 2007.

Melalui praktikum pserta didik juga dapat memplajari fisika dan pengamatan langsung terhadap gejala-gejala maupun proses-proses fisika, dapat melatih keterampilan berfikir ilmiah, dapat menanamkan dan mengembangkan sikap ilmiah, dapat menemukan dan memecahkan berbagai masalah baru melalui metode ilmiah dan lain sebagainya, keterampilan ini bisa dikembangkan melalui kegiatan praktikum. Dalam kegiatan praktikum peserta didik melakukan aktivitas seperti merancang percobaan, merangkai alat dan bahan yang digunakan, melakukan praktikum, mengemukakan hipotesis, menganalisis data, dan memprediksi dan menarik kesimpulan serta memberikan contoh-contoh nyata.

Berdasrkan observasi awal yang dilakukan peneliti pada tanggal 21 januari 2019 di SMPN 2 Bungku Selatan pada materi pokok IPA fisika getaran dan gelombang kelas VIII A dan VIII B memperoleh nilai lebih rendah dari nilai KKM yang diberlakukan disekolah yaitu 75 , hal ini disebabkan oleh beberapa faktor antara lain model pembelajaranh IPA-Fisika yang digunakan disekolah lebih didominasi model pembelajaran langsung yang dikembangkan dengan metode ceramah dan keterbatasan jumlah guru IPA-Fisika sehingga guru disekolah tersebut yang mengejar IPA-Fisika berlatar belakang biologi.

Untuk penerapan metode praktikumnya belum digunakan. Akan tetap pada saat proses 
pembelajaran berlangsung pada materi pokok yang diajarkan apabila materi mempunyai praktikum guru tersebut mendemonstrasikan di depan kelas, tidak melakukan praktikum secara langsung kepada peserta didik. Sekolah ini memiliki fasilitas, sarana, dan prasarana yang cukup memadai sebagai penunjang dalam proses belajar mengajar, secara khusus dalam pelajaran fisika. Sekolah memiliki laboratorium fisika yang cukup lengkap, akan tetapi laboratorium fisika belum digunakan secara maksimal. Sekolah ini jarang melakukan praktikum karena kekurangan guru fisika, sehingga guru fisika kesulitan dalam membagi waktu untuk melakukan praktikum.

Melalui praktikum peserta didik juga dapat memplajari fisika dan pengamatan langsung terhadap gejala-gejala maupun proses-proses fisika, dapat melatih keterampilan berfikir ilmiah, dapat menanamkan dan mengembangkan sikap ilmiah, dapat menemukan dan memecahkan berbagai masalah baru melalui metode ilmiah dan lain sebagainya, keterampilan ini bisa dikembangkan melalui kegiatan praktikum. Dalam kegiatan praktikum peserta didik melakukan aktivitas seperti merancang percobaan, merangkai alat dan bahan yang digunakan, melakukan praktikum, mengemukakan hipotesis, menganalisis data, dan memprediksi dan menarik kesimpulan serta memberikan contoh-contoh nyata.

Berdasarkan permasalahan yang diperoleh dari hasil observasi awal yang dilakukan peneliti di sekolah SMPN 2 Bungku Selatan maka peneliti telah melakukan penelitian dengan judul Penerapan Metode Praktikum untuk Meningkatkan Keterampilan Proses Sains dan Hasil Belajar Peserta Didik IPA Fisika pada Materi Pokok Getaran dan Gelombang Kelas VIII SMPN 2 Bungku Selatan.

\section{METODE}

Pada penelitian ini, peneliti menggunakan penelitian eksperimental kuantitatif. Dikatakan eksperimntal karena pada penelitian ini ada perlakuan pada partisipan dengaan metode praktikum (untuk kelas eksperimen) dan metode diskusi dan tanya jawab (untuk kelas kontrol), dikatakan kuantitatif karena data yang diperoleh dalam bentuk skor atau angka yang dianalisis dengan menggunakan statistik.

\section{Populasi dan Sampel Penelitian}

Pada penelitian ini, peneliti menggunakan penelitian eksperimental kuantitatif. Dikatakan eksperimntal karena pada penelitian ini ada perlakuan pada partisipan dengaan metode praktikum (untuk kelas eksperimen) dan metode diskusi dan tanya jawab (untuk kelas kontrol), dikatakan kuantitatif karena data yang diperoleh dalam bentuk skor atau angka yang dianalisis dengan menggunakan statistik.

\section{Desain atau Rancangan Penelitian}

Penelitian ini menggunakan desain PretestPosttest Control Group Design (Sugiyono, 2013). Selengkapnya disajikan sebagai berikut.

Tabel 1. Desain Protest-Posttestkelas esperimen dan kelas kontrol.

\begin{tabular}{cccc}
\hline Kelompok & Protest & Perlakuan & Pasttest \\
\hline KE & O1 & X & O2 \\
KK & O3 & Y & O4
\end{tabular}

Keterangan:

KE: Kelas Eksprimen

KK: Kelas Kontrol

O1: Pretest kelas eksperimenn

O2: Pasttest kelas eksperimen

O3: Pretest kelas kontrol

O4: Pasttest kelas kontrol

$\mathrm{X}$ : Perlakuan menggunakan metode praktikum

$\mathrm{Y}$ : Perlakuan menggunakan metode diskusi dan tanya jawab

Penelitian ini menggunakan beberapa instrumen penelitian yaitu: observasi dilakukan untuk melihat keterampilan prose sains peserta didik yang tampak selama proses pemblajaran berlangsung. Keterampilan proses tersebut meliputi keterampilan merumuskan masalah, merumuskan hipotesisi, merancang penelitian, melakukan prcobaan, mengelola data, mnyimpulkan dan mengomunikasikan. Teknik Dokumentasi berarti metode yang digunakan untuk mencari data yang diperlukan sebelum penelitian. Dokumentasi yang diperlukan adalah data hasil belajar siswa yang menjadi populasi penelitian sebelum proses pembelajaran. Tes, 
menurut Widoyoko, (dalam skripsi Andini) tes merupakan sejumlah pertanyaan yang harus ditanggapi seseorang dengan tujuan untuk mengukur kemampuan atau mengungkapkan aspek tertentu dari orang yang dikenai tes itu. Tes pada umumnya digunakan untuk menilai dan mengukur hasil belajar pesert didik, terutama hasil belajar kognitif berkaitan dengan penguasaan materi pelajaran sesuai dengan tujuan pendidikan dan pengjaran. Bentuk tes yang digunakan berupa soal pilihan ganda dan uraian. Ada dua bentuk tes yaitu: Protest diberikan sebelum pembelajaran dimulai. Protest bertujuan untuk mengetahui pemehaman awal peserta didik tentang konsep getaran dan gelombang. Soal protest sebanyak 22 butir yang terdiri dari aspek pengetahuan, pemahaman, dan penerapan. Posttest diberikan setelah pembelajaran selesai. Posttest bertujuan untuk mengetahui pemahaman peserta didik tentang konsep getaran dan gelombang setelah pembelajaran. Soal posttest sebanyak 22 butir yang terdiri dari aspek pengetahuan, pemehaman, dan penerapan.

Analisis data yang dilakukan menggunakan teknik statistik, yaitu statistik deskriptif dan statistik inferensial. Statistik deskriptif digunakan untuk mendeskripsikan nilai yang diperoleh masing-masing kelas dalam bentuk rata-rata, nilai maksimum, nilai minimum dan standar deviasi. Analisis statistik inferensial dimaksudkan untuk menguji hipotesis penelitian. Sebelum pengujian hipotesis, maka terlebih dahulu dilakukan pengujian dasar-dasar analisis sebagai pedoman untuk melakukan uji mana yang akan dipakai dengan menggunakan software SPSS 16.0. Uji normalitas data dimaksudkan untuk mengetahui apakah data yang diperoleh berasal dari populasi yang berdistribusi normal atau tidak. Pengujian normalitas data pre-test, post-test dan gain pada kelas eksperimen dan kelas kontrol menggunakan uji kolmogorov-smirnov.

\section{HASIL DAN PEMBAHASAN}

Deskripsi data pada penelitian ini berupa data tentang pre-test dan post-test hasil belajar siswa, baik peserta didk kelas eksperimen maupun peserta didik kelas kontrol. Gambaran hasil belajar siswa pada kelas eksperimen dan kelas kontrol lebih lengkap dapat dilihat pada lampiran. Secara ringkas disajikan pada Tabel 1 berikut.

Tabel 2. Data Hasil Belajar IPA Fisika Peserta Didik Kelas Eksperimen dan Kelas Kontrol.

\begin{tabular}{lcrrc}
\hline \multirow{2}{*}{ Nilai } & \multicolumn{2}{c}{ Kelas Eksperimen } & \multicolumn{2}{c}{ Kelas Kontrol } \\
\cline { 2 - 5 } & Pre-Test & Post-Test & Pre-Test & Post-Test \\
\hline Rata-rata & 36,195 & 77,60 & 37,54 & 71,04 \\
St. Deviasi & 9,55 & 10,98 & 10,59 & 9,777 \\
Maksimum & 54,545 & 90,90 & 54,54 & 90,90 \\
Minimum & 13,636 & 54,54 & 18,18 & 50 \\
\hline
\end{tabular}

Dari tabel 4.1 secara umum dapat dilihat bahwa nilai rata-rata hasil belajar fisika peserta didik kelas eksperimen dan siswa kelas kontrol samasama mengalami peningkatan. Hal ini dibuktikan dengan nilai rata-rata hasil pretest siswa kelas eksperimen mengalami peningkatan yaitu dari 36,195 menjadi 77,609 pada posttest. Begitu pula nilai rata-rata hasil belajar peserta didik kelas kontrol yang mulanya 37,542 pada saat pretest menjadi 71,044 pada saat posttest.

\section{Data laporan akhir praktikum}

Berikut merupakan skor laporan praktkum peserta didik yang diperoleh dari kegiatan pembelajaran yang dilakukan dengan menggunakan metode praktiikum.

Tabel 3. Nilai Laporan Praktikum Kelompok Kelas Eksperimen.

\begin{tabular}{cccc}
\hline Kelompok & Praktikum 1 & Praktkum II & Praktikum III \\
\hline 1 & 5,4 & 6,4 & 7 \\
2 & 4,8 & 5,5 & 5,8 \\
3 & 6,4 & 6,4 & 7 \\
4 & 6,4 & 6,8 & 7
\end{tabular}




\section{Keterampilan Proses Sains Peserta didik}

Keterampilan Proses Sains Peserta Didik Kelas Eksperimen

Data mengenai keterampilan proses sains peserta didik kelas eksperimen yang diperoleh menggunakan lembar observasi dengan cara memberikan skor pada setiap aspek keterampilan prosese sains yang dilakukan oleh setiap kelompok sesuai dengan kriteria yang telah ditentukan. Data skor rata-rata keterampilan proses sains tiap kelompok dalam proses pembelajaran pada LKPD 01, LKPD 02 dan LKPD 03 dapat dilihatt pada Tabel 4 berikut.

Tabel 4. Data KPS Kelompok Peserta Didik Kelas Eksperimen

\begin{tabular}{clccc}
\hline \multirow{2}{*}{ No } & \multirow{2}{*}{ Aspek KPS } & LKPD 01 & LKPD 02 & LKPD 03 \\
\cline { 3 - 5 } & & Part 1 & Part 2 & Part 3 \\
\hline 1 & Mengamati & 2,2 & 2,8 & 3 \\
2 & Merumuskan Masalah & 2,2 & 2,6 & 2,8 \\
3 & Berhipotesis & 2,4 & 2,6 & 2,8 \\
4 & Mengumpulkan Data & 2,6 & 2,8 & 3 \\
5 & Menyimpulkan & 2,2 & 2,6 & 2,8 \\
6 & Rata-Rata Skor & 2,3 & 2,7 & 2,9 \\
\hline 7 & Kategori & cukup & cukup & Cukup \\
\hline
\end{tabular}

Keterangan : KPS = Keterampilan Proses Sains

Dari Tabel 4.3 tersebut terlihat bahwa skor rata-rata keterampilan proses sins peserta didik pada LKPD 01 dan LKPD adalah 2,3 dengan kategori cukup dan 2,7 dengan kategori cukup. Sedangkan pada LKPD 03 adalah 2,9dengan kategori cukup. Berdasarkan data tersebut dapat dikatakan bahwa keterampilan proses sains peserta didik mengalami peningkatan dari LKPD 01 hingga LKPD 03.

Kterampilan Proses Sains Peserta Didik Kelas Kontrol
Data mengenai keterampilan proses sains peserta didik kelas kontrol yang diperoleh menggunakan lembar observasi dengan cara memberikan skor pada setiap aspek keterampilan prosese sains yang dilakukan oleh setiap kelompok sesuai dengan kriteria yang telah ditentukan. Data skor rata-rata keterampilan proses sains tiap kelompok dalam proses pembelajaran pada LKPD 01, LKPD 02 dan LKPD 03 dapat dilihatt pada Tabel 4.2 berikut:

Tabel 5. Data KPS Kelompok Peserta Didik Kelas Eksperimen.

\begin{tabular}{llccc}
\hline \multirow{2}{*}{ No. } & \multirow{2}{*}{ Aspek KPS } & LKPD 01 & LKPD 02 & LKPD 03 \\
\cline { 3 - 5 } & & Part 1 & Part 2 & Part 3 \\
\hline 1 & Mengamati & 2,2 & 2,8 & 3 \\
2 & Merumuskan Masalah & 2,2 & 2,6 & 2,8 \\
3 & Berhipotesis & 2,4 & 2,6 & 2,8 \\
4 & Mengumpulkan Data & 2,6 & 2,8 & 3 \\
5 & Menyimpulkan & 2,2 & 2,6 & 2,8 \\
6 & Rata-Rata Skor & 2,3 & 2,7 & 2,9 \\
\hline 7 & Kategori & Cukup & Cukup & Cukup \\
\hline
\end{tabular}

Dari Tabel 4.4 tersebut terlihat bahwa skor rata-rata keterampilan proses sins peserta didik pada LKPD 01 dan LKPD adalah 2,3 dengan kategori cukup dan 2,5 dengan kategori cukup. Sedangkan pada LKPD 03 adalah 2,8 dengan kategori cukup. Berdasarkan data tersebut dapat dikatakan bahwa keterampilan proses sains peserta didik mengalami peningkatan dari LKPD 01 hingga LKPD 03. Hasil Analisis Inferensial melalui Analisis Dasar-dasar 
Statistik yaitu uji normalitas data. Dimana hasil uji normalitas data hasil belajar peserta didik yang belajar melalui metode praktikum dan Tabel 6. Rangkuman Hasil Uji Normalitas Data Hasil Belajar Peserta Didik Kelas Eksperimen dan Kelas Kontrol.

\begin{tabular}{lccccc}
\hline Kelas & $\begin{array}{c}\text { Aspek yang } \\
\text { Diuji }\end{array}$ & $\begin{array}{c}\text { Kolmogorov- } \\
\text { Smirnov }\end{array}$ & Asymp.Sig & A & \multirow{2}{*}{ Ket } \\
\hline \multirow{2}{*}{ Eksperimen } & Pre-Test & 0,675 & 0,752 & 0,05 & Normal \\
& Post-Test & 0,138 & 0,440 & 0,05 & Normal \\
\hline \multirow{2}{*}{ Kontrol } & Pre-Test & 0,744 & 0,637 & 0,05 & Normal \\
& Post-Test & 0,644 & 0,801 & 0,05 & Normal \\
\hline
\end{tabular}

Tabel 5 menunjukkan bahwa nilai signifikan untuk pre-test kelas eksperimen adalah 0,752 lebih besar dari $\alpha=0,05$, dengan demikian dapat disimpulkan bahwa data hasil belajar terdistribusi normal. Begitu pula pada post-test kelas eksperimen dan pre-test dan post-test kelas kontrol nilai signifikan lebih besar dari $\alpha=$ 0,05 , sehinggga dapat disimpulkan bahwa data hasil belajar terdistribusi normal pada $\alpha=0,05$.

1) Uji Homogenita

Hasil uji homogenitas varians data hasil belajar peserta didik yang belajar melalui metode diskusi dan tanya jawab menggunakan uji Kolmogorov-Smirnov secara singkat dirangkum dalam Tabel 5.

Tabel 7. Rangkuman Uji Hipotesis Data Pre-Test Hasil Belajar Peserta Didik.

\begin{tabular}{llcc}
\hline Kelas & $\mathrm{N}$ & Sig. (2-tailed) & Kepastian \\
\hline Eksperimen & 27 & 0,626 & $\mathrm{H}_{0}$ ditolak dan $\mathrm{H}_{1}$ diterima \\
Kontrol & 27 & & \\
\hline
\end{tabular}

Hasil uji beda nilai rata-rata pre-test hasil belajarpeserta didik kelas eksperimen dan kelas kontrol menggunakan uji independent samples $t$ test terlihat bahwa nilai Sig. (2-tailed) adalah 0,626 lebih besar dari $\alpha=0,05$ yang berarti $\mathrm{H}_{0}$ metode praktikum dan metode diskusi dan tanya jawabmenggunakan uji Levene Statistic diperolehnilai signifikan 0,805 lebih besar dari $\alpha=0,05$ sehingga dapat disimpulkan bahwa kedua kelompok memiliki varians yang sama. Jadi, data hasil belajar fisika siswa yang belajar melalui metode praktikum dan metode diskusi dan tanya jawab adalah homogen pada $\alpha=0,05$.

2) Pengujian Hipotesis

a. Pengujian Hipotesis I

Tabel 8. Rangkuman Uji Hipotesis Data Post-Test Hasil Belajar Peserta Didik.

\begin{tabular}{llcc}
\hline Kelas & $\mathrm{N}$ & Sig. (2-tailed) & Kepastian \\
\hline Eksperimen & 27 & 0,024 & $\mathrm{H}_{0}$ ditolak dan $\mathrm{H}_{1}$ diterima \\
Kontrol & 27 & & \\
\hline
\end{tabular}

Hasil uji beda nilai rata-rata post-test hasil belajarpeserta didik kelas eksperimen dan kelas kontrol menggunakan uji independent samples $T$ test terlihat bahwa nilai Sig. (2-tailed) adalah 0,024 lebih kecil dari $\alpha=0,05$ yang berarti $\mathrm{H}_{0}$ ditolak dan $\mathrm{H}_{1}$ diterima. Dengan demikian dapat disimpulkan nilai rata-rata post-test hasil belajar peserta didik kelas eksperimen lebih baik secara diterima dan $\mathrm{H}_{1}$ ditolak. Dengan demikian dapat disimpulkan tidak ada perbedaan antara nilai rata-rata pre-test hasil belajar peserta didik kelas eksperimen dan kelas kontrol.

b. Pengujian Hipotesis II 
beberapa faktor, baik faktor dari dalam diri peserta didik maupun faktor dari luar diri peserta didik. Salah satu faktor yang cukup menentukan hasil belajar peserta didik adalah proses belajar mengajar di kelas.

Data yang dianalisis dalam penelitin ini diperoleh dengan cara pemberin prettest sebelum diberikan pembelajaran dan posttest setelah diberikan pembelajaran. Dari data tersebut kemudian dilihat peningkatann hasil belajar peserta didik, digunakan perbandingan nilai preteest dan nilai posttest peserta didik. Untuk hasil belajar jika dilihat dari hasil pretest peserta didik sebelum pembelajaran dimulai, rata- rata hasil belajar peserta didik kelas eksperimen maupun kelas kontrol sangat rendah yaitu 36,195 untuk kelas eksperimen dan 37,542 untuk kelas kontrol. Hasil tersebut sejalan dengan pengujian inferensial pada $\alpha=$ 0,05 bahwa tidak ada perbedaan rata-rata pretest hasil belajar kelas eksperimen dan kelas kontrol. Hal ini disebabkan kedua kelas belum memperoleh materi getaran dan gelombang secara detail. Nilai rata-rata dari kedua kelas ini akan menjadi tolak ukur untuk melihat peningkatan hasil belajar peserta didik pada tes akhir setelah diberikan perlakuan.

Setelah pembelajaran materi getaran dan gelombang selesai, hasil belajar baik peserta didik kelas eksperimen maupun kelas kontrol mengalami peningkatan atau dapat dikatakan terjadi suatu kemajuan hasil belajar. Hasil belajar merupakan kemampuan yang dimiliki peserta didik setelah mengalami proses belajar atau dapat dikatakan sebagai suatu ukuran keberhasilan peserta didik dalam memahami materi yang telah diberikan. Secara deskriptif, rata-rata hasil belajar peserta didik setelah pembelajaran (post-test) pada kelas eksperimen lebih baik dari kelas kontrol yaitu sebesar 77,609 sedangkan kelas kontrol sebesar 71,044. Meskipun hasil belajar kelas eksperimen lebih baik dari kelas kontrol namun hasil belajar yang diperoleh belum sesuai harapan karena pada saat proses pembelajaran berlangsung serta pada saat dilaksanakan post-test, sebagian besar peserta didik tidak mempersiapkan diri dalam hal ini belajar karena bertepatan dengan beberapa ulangan pada pelajaran lain. Secara inferensial dengan menggunakan uji independent sampel $t$ test terlihat bahwa nilai Sig. (2-tailed) adalah 0,024 lebih kecil dari $\alpha=$ 0,05 menunjukkan bahwa hasil belajar peserta didik setelah dilakukan pembelajaran pada kelas eksperimen lebih baik secara signifikan daripada kelas kontrol.

Hasil penelitian ini didukung oleh penelitian Azhar (2002) bahwa belajar yang paling baik adalah melalui pengalaman langsung. Dalam pencapaian bahan menggunakan kegiatan dan pengalaman langsung, kegiatan dan pengalaman demikian lebih menarik perhatian peserta didik. Sebab peserta didik bekerja langsung dengan contohcontoh nyata, peserta didik lngsung mengaplikasikan kemampuaannya, peserta didik langsung menerapkan prinsip-prinsip dan langkah-langkah pemecahan masalah dan memberikan kesempatan bagi keterlibatan peserta didik dalam situasi belajar.

Berbeda halnya dengan proses pembelajaran pada kelas kontrol, dimana proses pembelajaran berlangsung secara klasikal guru menjelaskan materi pembelajaran dengan menggunakan metode diskusi dan tanya jawab sehingga peserta didik hanya menerima pemaparan dari guru. Jadi pada kelas kontrol, guru mendominasi aktivitas pembelajaran dalam kelas sehingga peserta didik cenderung tidak aktif dan hanya menerima apa yang disampaikan oleh guru.

Hasil analisis deskriptif keterampilan proses sains peserta didik jika dilihat dari hasil LKPD 01, LKPD 02, dan LKPD 03, seluruh nilai skor rata-rata peserta didik baik kelas eksperimen maupun kelas kontrol termasuk dalam kategori cukup. Rata-rata skor keterampilan proses sains kelas eksperimen yaitu sebesar 2,3, 2,7 dan 2,9. Untuk keterampilan proses sains kelas kontrol yaitu sebesar 2,3, 2,5 dan 2,8 dengan kategori yang sama yaitu katetgori cukup. Keterampilan proses sains peserta didik kelas eksperimen maupun kelas kontrol sama-sama mengalami peningkatan dari LKPD 01 sampai LKPD 03. Hal tersebut dikarenakan keterampilan proses sains dari kedua kelas mengalami peningkatakan untuk kelas eksperimen dan kelas kontrol dilihat dari masing-masing peningkatan indikator keterampilan proses sains. Dimana indikator keterampilan proses 
sains yang digunakan untuk kelas ekperimen dan kelas kontrol yaitu mengmati, merumuskan masalah, berhipotesis mengumpulkan data dan menyimpulkan. Hasil penelitian ini didukung oleh penelitian subiantoro (2005) menyatakan bahwa pembelajaran praktikum memiliki peran dalam pengembangan proses sains peserta didik. Penerapan keterampilan proses sains sekaligus pengembangan sikap ilmiah yang mendukung proses pengetahuan dalam diri peserta didik sangat dimungkinkan dalam kegiatan praktik, sehingga dalam pembelajaran IPA praktikum memiliki kedudukan yang amat penting. Hal tersebut sesuai dengan pendapat Nuryani dalam Sudargo dan Asiah (2009) bahwa praktikum merupakan sarana terbaik untuk meengembangkan keterampilan proses sains, karena dalam praktikum peserta didik dilatih untuk mengembangkan semua indranya.

Berdasarkan uraian tersebut, bahwa pembelajaran dengan menggunakan metode praktikum dapat meningkatkan hasil belajar dan keterampilan proses sains peserta didik. Hal ini karena penerapan metode praktikum berupaya meningkatkan kemampuan peserta didik dalam menyelesaikan masalah dan dapat dihubungkan ke dalam konteks nyata kehidupan peserta didik melalui percobaan sehingga peserta didik tidak mudah kehilangan konsep dasarnya. Penelitian ini relevan dengan penelitian yang sudah pernah dilakukan oleh Rustam (2011) bahwa terdapat pengaruh yang signifikan untuk penggunaan metode praktikum dengan terhadap keterampilan proses sains dan hasil belajar peserta didik pada materi getaran dan gelombang.

\section{KESIMPULAN}

Berdasarkan rumusan masalah dan hasilhasil analisis data penelitian dapat disimpulkan sebagai berikut:

1. Gambaran hasil pre-test dan post-test peserta didik kelas eksperimen pada materi pokok getaran dan gelombang yaitu nilai rata-rata pre-test sebesar 36,195 dan standar deviasi 9,55, untuk post-test nilai rata-rata 77,609, dan standar deviasi 10,985, sedangkan pada kelas kontrol yaitu nilai rata-ratapre-test sebesar 37,542 dan standar deviasi 10,592, untuk post-test nilai rata-rata 71,044 dan standar deviasi 9,773.

2. Gambaran hasil belajar keterampilan proses sains peserta didik kelas eksperimen yaitu nilai rata-rata skor LKPD 01 2,6, LKPD 02 2,7, dan LKPD 03 2,9, sedangkan untuk keterampilan proses sains peserta didik kelas kontrol yaitu nilai rata-rata skor LKPD 01 2,5, LKPD 02 2,7, dan LKPD 03 2,8, dengan kategori yang sama yaitu kategori cukup.

3. Tidak ada perbedaan antara nilai rata-rata hasil belajar pre-test peserta didik kelas eksperimen dengan nilai rata-rata pre-test peserta didik kelas kontrol.

4. Nilai rata-rata post-test peserta didik kelas eksperimen lebih baik secara signifikan daripada nilai rata-rata post-test peserta didik kelas kontrol.

\section{DAFTAR PUSTAKA}

Arikunto, S. 2018. Dasar-Dasar Evaluasi Pendidikan Edisi Revisi. Jakarta PT. BumiAksara.

Azhar dan Poniman. 2016. Upaya Peningkatan Aktivitas dan Hasil Belajar Fisika dengan Metode Praktikum pada Siswa Kelas XI IPA MAN 1 Kalinda Lampung Selatan. Jurnal Ilmiah Pendidikan Fisika Al-BiruNi 05 (2) (2016). ISSN: 2303-1832. Lampung Selatan: FTIK IAIN Raden Intan Lampung.

Baharudin dan Wahyuni Nur Esa 2008. Teori Belajar Dan PembbelajaranYogyakarta: Arruz Media.

Connat, James. 2011. Activities For Teaching Science as Inquiry. New Jersey:Pearson Merill Prentice Hall.

Dimyanti dan Mudjono. 2009. Belajar dan Pembelajaran. Jakarta: Rineka Cipta.

Damyati dan Mudjono. 2006. Belajar dan Pembelajaran. Jakarta: Rineka Cipta

Dariyanto. 1999. Evaaluasi Pendidikan. Jakarta: Rineka Cipta.

Djamrah, Syaiful Bahri dan Aswan Zain. 1996. Strategi Belajarr Mengajar. Jakarta: Rineka Cipta.

Kanginan Marthen. 2002. IPA Fisika 2 untuk SMP Kelas VIII Berdasarkan Standar Isi 2006. Jakarta: Erlangga.

Lestari Mega Yati dan Diana Nirvana. 2016. Keterampilan Proses Sains (KPS) 
pada Pelaksanaan Praktikum Fisika Dasar 1. https://ejournal.radenintan.ac.id/index.ph p/IJSME/index. Lampung: FTK UIIN Rade n Intan Lampun

Mulyasa, E. 2004. Implementasi Kurikulum 2004 Panduan Pembelajaran KBK. Bandung: Remaja Rosdakarya.

Ozgelen, Sinan. 2012. Students Science Process Skills Within a Cognitive Domain Fremework. Eurasia Journal Of Mhatematics: Scince and Technology Educasion. 8 (4): 283:292.

Rustaman, Nuryana Y 2005. Perkembangan Penelitian Pembelajaran Berbasis Inkuiridalam Pendidikan Sains. Seminar Nasional II Himpunan IkatanSarjana danPemerhati Pendidikan IPA Indonesia Bekerjasama dengan FPMIPA Universitas Pendidikan Indonesia. Bandung: 22-23 Juli 2005.
Semiawan, CA, Tahyong, F, Belen, S, Matahaemual, Y, dan Suseloardjo, W. 1992. Pendekatan Keterampilan Proses. Jakarta: Gramedia.

Suyatno, Slamet. 2005. Pembelajaran dalam Implementasi Kurikulum Kompetensi. Jakarta: Kencana.

Sudijono Anas. 1998. Pengantar Evaluasi Pendidikan. Jakarta: PT. Raja Grafindo Persada.

Suhjana, Nana. 1998. Penilain Proses Hasil Belajar Mengajar. Bandung: Remaja Rosda Karya.

Suparno, Paul. 2011. Pengantar Statistika untuk Pendidikan dan Psikologi (untuk mahasiswa). Yogyakarta: Universitas Sanata Dharma.

Wisudawati Widi Asih dan Sulistyowati Eka. 2013. Metedologi Pembelajaran IPA. Jakarta: Bumi Angkasa. 